\title{
IDŐJÁRÁS
}

Quarterly Journal of the Hungarian Meteorological Service

Vol. 125, No. 2, April-June, 2021, pp. 321-336

\section{Changes in extreme precipitation over the North Caucasus and the Crimean Peninsula during 1961-2018}

\author{
Elena Vyshkvarkova \\ Institute of Natural and Technical Systems \\ Lenin St. 28, Sevastopol, 299011, Russian Federation \\ aveiro_7@mail.ru
}

(Manuscript received in final form June 8, 2020)

\begin{abstract}
Based on daily meteorological data, spatial and temporal distributions of extreme precipitation in 1961-2018 were examined for the North Caucasus and the Crimean Peninsula. Extreme precipitation indices recommended by the Expert Team for Climate Change Detection and Indices were calculated for 45 meteorological stations. Analysis shows that the highest values of extreme precipitation indices are on the Black Sea coast of the Caucasus, except duration of dry spell, because of the atmospheric circulation features and the complex orography of studied area. Extreme precipitation trends are spatially incoherent and mostly statistically insignificant over the studied territory. Significant upward trends on the Caspian Sea coast and Stavropol Upland and statistically significant decreasing trends in the fixed threshold-based indices and all intensity indices over the Crimean Peninsula were detected. Positive and significant correlation between precipitation indices (except consecutive dry days) and altitude was obtained.

Key-words: extreme precipitation, indices, trend, North Caucasus, Crimean Peninsula
\end{abstract}

\section{Introduction}

The observed trend of climate change has been particularly noticeable since the 1970s (Hartmann et al., 2013). Against the backdrop of global air temperature trends, cases of extreme events associated with precipitation in the middle latitudes of the Northern Hemisphere are becoming more frequent (IPCC, 2014). Changes in extreme precipitation are of great interest around the world because of its huge potential impact on efficiency of the activities in many sectors of economy and human life (Changnon et al., 2000; Zhang et al., 2017). 
Extremely low precipitation leads to drought, wildfires, swallowing of rivers, hindered navigation and water supply, and crop losses (Ray et al., 2015). Droughts in many Russian regions and subsequent wildfires caused great disasters in 2010, 2012, and 2019. In reverse, heavy rainfall causes floods, erosion, and landslides in the mountains. A good example is the floods in Krasnodar Krai of Russia in early July 2012, when the equivalent of two-five months precipitation norm fell in short time (Meredith et al., 2015, Kotlyakov et al., 2013). Lack of water in reservoirs on the Crimean Peninsula, Krasnodar Krai, and other regions of Northern Caucasus in 2019 resulted from abnormally warm weather and prolonged lack of precipitation.

Unlike temperature extremes, the distribution of extreme precipitation is spatially and temporally incoherent in many regions (Frich et al., 2002; Alexander et al., 2006; Donat et al., 2013). Precipitation extremes have been studied in many regions all over the world, e.g., in Asia (Limsakul and Singhruck, 2016; Khan et al., 2019; Wang et al., 2012; Liu et al., 2013; Tong et al., 2019; Yang et al., 2019; Nie et al., 2019), Europe (Klein Tank and Konnen, 2003; Mathbout et al., 2018; Popov et al., 2018; Bartolomeu et al., 2016; Lupikasza, 2010), and North America (Brown et al., 2010; Sayemuzzaman and Jha, 2014).

Previous studies in Russia have also found spatially and seasonally incoherent patterns of change in extreme precipitation. The conclusion thereof, as reflected in the Second Roshydromet Assessment Report on Climate Change and its Consequences in the Russian Federation across the European part of Russia, is that there was an increase in annual rainfall over 1936-2010 (Second Roshydromet Assessment Report, 2014). For the southwestern part of Siberia, no significant trends were observed over 1969-2011 in relative and absolute precipitation indices (ETCCDI indices) at the regional level (Degefie et al., 2014). In the densely populated territories of Russia, the frequency of extreme winter precipitation has increased by an average of $20-40 \%$. Rising occurrence rates of extreme summer precipitation were observed in the Central Black Earth Region of the European part of Russia over 1961-2013 (Zolotokrylin and Cherenkova, 2017). In 2000-2015, extreme winter precipitation was observed on a greater number of days per year compared to 1970-1999 in the European part and in the southern part of Russia (Titkova et al., 2018). Paper Ye (2018) identifies a correlation between air temperature and wet/dry periods: higher air temperatures were consistently associated with longer dry periods and shorter wet periods in summer. Opposite tendencies in annual precipitation amount, daily precipitation maximum, and number of days with precipitation in different seasons were obtained for foothill and steppe zones in the central part of North Caucasus for 1955-2004 (Ashabokov et al., 2008). Later Tashilova et al. (2019) found not unidirectional changes in the precipitation regime in the Caucasian region during 1961-2011.

Whether globally or specifically in Russia, there are no clear patterns of extreme precipitation. The goal, hereof, is to investigate the spatio-temporal variability of extreme precipitation over North Caucasus and the Crimean Peninsula for 1961-2018. 


\section{Data and methods}

\subsection{Study area}

The studied area includes the territory of the North Caucasus and the Crimean Peninsula. The North Caucasus consists of the northern slopes of the Greater Caucasus Mountains and Ciscaucasia. The northern border of Caucasus passes through the Kuma-Manych Depression, the Sea of Azov, and the Kerch Strait. It is bounded by the Black Sea in the west. The region is located on the border of temperate and subtropical latitudes, not far from the warm Mediterranean Sea. The movement of air masses and their transformation in the territory of the North Caucasus are extremely complex and diverse. Cyclones nearly always come from the west or northwest, and as they move to the east and southeast, the air masses they bring lose moisture. The western lowlands of Ciscaucasia are more humid than their eastern part. In the west, the annual precipitation is $380-520 \mathrm{~mm}$, and in the Caspian region, it is only 220-250 $\mathrm{mm}$. In the foothills and the Stavropol Upland, precipitation rises to $600-650 \mathrm{~mm}$. The situation is further complicated by the extreme irregularity of precipitation over time. The eastern part of the studied region (the Caspian Sea coast) shows a high precipitation concentration index (Vyshkvarkova et al., 2018), which allows to detect relative contribution of rainy days to the total amount (Martin-Vide, 2004). Mountain slopes are much better moistened: in the mountains of the Western Caucasus at altitudes above $2000 \mathrm{~m}, 2500-2600 \mathrm{~mm}$ precipitation falls in a year; to the east, their number decreases to $900-1000 \mathrm{~mm}$.

The Crimean Peninsula has a diverse climate and includes several types of it: steppe, subtropical, and mountain climate. The average annual rainfall varies from $250 \mathrm{~mm}$ in the steppe zone to $1000 \mathrm{~mm}$ and more in the Crimean Mountains.

\subsection{Data source and methodology}

The analysis of changes in extreme climate indices over 1961-2018 was carried out using climatological data set of daily precipitation collected at 45 meteorological stations over the North Caucasus and the Crimean Peninsula (Fig. 1). One station is located in Caspian Sea on Tyuleny Island. Data were provided by the All-Russian Research Institute of Hydrometeorological Information - World Data Centre (RIHMI-WDC) (http://aisori-m.meteo.ru). 


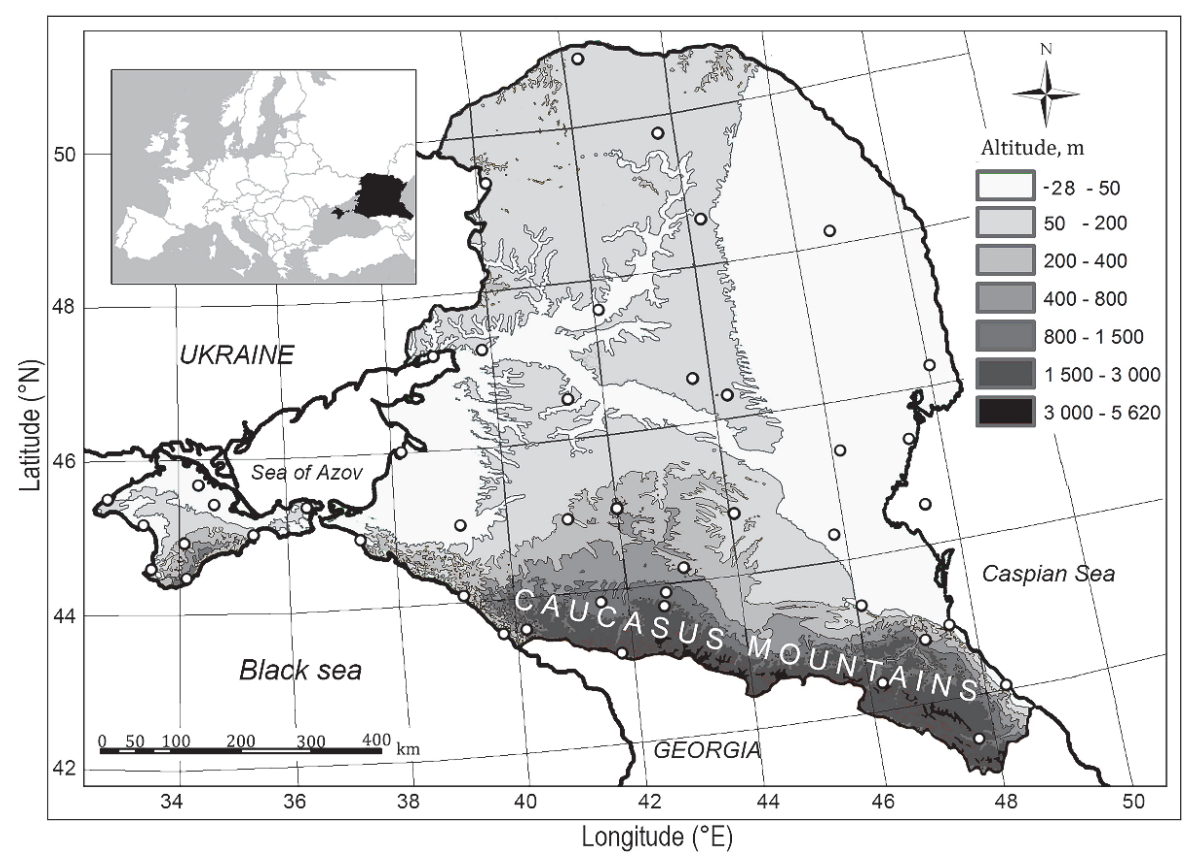

Fig. 1. Studied area and location of meteorological stations.

The input data were used for calculation of 10 extreme climate indices recommended by the CCl/CLIVAR Expert Team for Climate Change Detection and Indices (ETCCDI) for climate change assessment (http://www.clivar.org/organization/etccdi). Definition of extreme precipitation indices is presented in Table 1. Data quality control and indices calculating were done using RClimDex software developed by Zhang and Yang (2004) (freely available from http://etccdi.pacificclimate.org/software). Extreme precipitation indices are usually divided into two groups: indices in precipitation (RX1day, RX5day, PRCPTOT, R95p, R99p) and SDII, and indices in the number of precipitation days (R10 mm, R20 mm, CDD and CWD) (Wang et al., 2013, Liu et al., 2013). Indices also can be divided into fixed threshold-based indices (R10 and R20), duration-based indices (CDD and CWD), absolute indices (RX1day, RX5day, PRCPTOT and SDII), and percentile-based indices (R95p and R99p) (Alexander et al., 2006).

The trend magnitudes were calculated using the non-parametric Sen's slope estimator (Sen, 1968) and the least squares method. Statistical significance of the trends was detected depending on the Mann-Kendall test with a 95\% confidence level (Mann, 1945; Hamed and Rao, 1998). The probability density functions for each index were calculated for two subperiods: 1961-1990 and 1991-2018. The two-tailed nonparametric Kolmogorov-Smirnov test was performed to test whether the distributions changed significantly between the two specified periods and to confirm observed trends (Dodge, 2008). The Pearson's correlation coefficient was used to analyze the relationship between extreme precipitation indices and altitude. All tests and calculations were performed in XLSTAT Version 2014.5.03. 
Table 1. Definition of extreme precipitation indices used in the study

\begin{tabular}{|c|c|c|c|}
\hline ID & Indicator name & Definition & Units \\
\hline $\mathrm{CDD}$ & Consecutive dry days & $\begin{array}{l}\text { Maximum number of consecutive days } \\
\text { when precipitation } \leq 1 \mathrm{~mm}\end{array}$ & days \\
\hline CWD & Consecutive wet days & $\begin{array}{l}\text { Maximum number of consecutive days } \\
\text { when precipitation } \geq 1 \mathrm{~mm}\end{array}$ & days \\
\hline PRCPTOT & $\begin{array}{l}\text { Annual total wet-day } \\
\text { precipitation }\end{array}$ & $\begin{array}{l}\text { Annual total precipitation from days } \geq \\
1 \mathrm{~mm}\end{array}$ & $\mathrm{~mm}$ \\
\hline $\mathrm{R} 10 \mathrm{~mm}$ & $\begin{array}{l}\text { Number of heavy } \\
\text { precipitation days }\end{array}$ & $\begin{array}{l}\text { Number of days per year when } \\
\text { precipitation } \geq 10 \mathrm{~mm}\end{array}$ & days \\
\hline $\mathrm{R} 20 \mathrm{~mm}$ & $\begin{array}{l}\text { Number of very heavy } \\
\text { precipitation days }\end{array}$ & $\begin{array}{l}\text { Number of days per year when } \\
\text { precipitation } \geq 20 \mathrm{~mm}\end{array}$ & days \\
\hline RX1day & $\begin{array}{l}\text { Max 1-day precipitation } \\
\text { amount }\end{array}$ & Annual maximum 1-day precipitation & $\mathrm{mm}$ \\
\hline RX5day & $\begin{array}{l}\text { Max 5-day precipitation } \\
\text { amount }\end{array}$ & $\begin{array}{l}\text { Annual maximum consecutive 5-day } \\
\text { precipitation }\end{array}$ & $\mathrm{mm}$ \\
\hline SDII & Simple daily intensity index & $\begin{array}{l}\text { The ratio of annual total precipitation to } \\
\text { the number of wet days }(\geq 1 \mathrm{~mm})\end{array}$ & $\mathrm{mm} /$ day \\
\hline R95p & Very wet days & $\begin{array}{l}\text { Annual total precipitation from days } \geq \\
\text { 95th percentile }\end{array}$ & $\mathrm{mm}$ \\
\hline R99p & Extremely wet days & $\begin{array}{l}\text { Annual total precipitation from days } \geq \\
\text { 99th percentile }\end{array}$ & $\mathrm{mm}$ \\
\hline
\end{tabular}

\section{Results}

\subsection{Spatial distribution of extreme precipitation indices}

Consecutive dry days (CDD) and wet days (CWD) are duration indices based on the maximum duration of dry and wet periods. CDD values over the studied area varied from 19 to 55 days and peaked in the Caspian Sea coastal zone (Tyuleny Island). The Black Sea coast has the lowest CDD index. In the steppe part of the studied region, the index is 29-33 days. In Crimea, the index varies from 31 days on the south coast to 41 days in the north. The opposite patterns are typical for the CWD index. The lowest values are observed for the coast of the Caspian Sea ( 3 days), and the highest are found on the Black Sea coast of Caucasus and on high mountain stations (up to 10 days). In Crimea, the index is 5-6 days. All indices, except CDD peak on the Black Sea coast, decrease towards the north and northeast. 
Spatial distribution of the PRCPTOT index values corresponds to the annual precipitation. The highest values $(1600-1800 \mathrm{~mm})$ are found high in the mountains. This region features the greatest total precipitation of different types (showery and compound) in Russia (Chernokulsky et al., 2018 over 1966-2014). The coast of the Caspian Sea has the lowest value of the index. On the Black Sea coast of Caucasus, the annual precipitation increases southwards from $500 \mathrm{~mm}$ in Anapa to $1600 \mathrm{~mm}$ in Sochi. Over the Crimean Peninsula, PRCPTOT rises from the north (about $400 \mathrm{~mm}$ ) to the south towards the Crimean Mountains.

Indices $\mathrm{R} 10 \mathrm{~mm}$ and $\mathrm{R} 20 \mathrm{~mm}$ are frequency indices which are based on the absolute threshold. They represent the number of days of heavy and very heavy rainfall when the daily precipitation is 10 or $20 \mathrm{~mm}$ higher, respectively. R10mm ranges from 4 to 63 days per year. The number of heavy precipitation days rises from NW to SE over the North Caucasus and peaks on the western slopes. In the Crimea, the index varies from 9 to 18 days.

$\mathrm{R} 20 \mathrm{~mm}$ index has an identical spatial distribution. Values range from 1 day on the Tyuleny Island to 33 days per year in the mountains. It varies from 2 to 5.5 days/year in the Crimea. The annual index RX1day $(90 \mathrm{~mm})$ peaks in the Kluxor Pereval (a mountain pass across the Main Caucasian Range). Large values were also observed for the Black Sea coast of the Caucasus (Sochi region) (as in Ashabokov et al. (2017) over 1961-2011). Eastern arid zone has low values of RX1day index (about $30 \mathrm{~mm}$ ). The Crimean Peninsula has a fairly even distribution of the index (30-40 mm). The annual index RX5day ranges from 35 to $180 \mathrm{~mm}$. It varies within $40-70 \mathrm{~mm}$ in the Crimea and peaks on the Black Sea coast. These indices represent the maximum single-day and consecutive five-day precipitation amounts, respectively, to provide information about the most rainy periods of the year; they are a potential flood indicator. A simple index of precipitation intensity (SDII) also peaks on the Black Sea coast of the Caucasus (14 mm/day), and it is minimal in the east of the studied region (about $5 \mathrm{~mm} /$ day). It varies slightly $(5-7 \mathrm{~mm} /$ day $)$ in the Crimea.

The highest value (350-450 mm) for annual total precipitation on days above the 95th percentile (R95p) is found on the Black Sea coast of the Caucasus Mountains, and the lowest value is for the north-eastern part of the studied area and the northern coast of the Caspian Sea.

The North Caucasus and the Crimean Peninsula mainly have R95p of about $30-40 \mathrm{~mm}$. The eastern arid region has the lowest R99p (about $20 \mathrm{~mm}$ ). The Black Sea coast of the Caucasus has the highest annual total precipitation on days above the 99th percentile $(110-150 \mathrm{~mm})$.

\subsection{Trends in precipitation extremes}

Table 2 shows the generalized results of trend analysis and the percentage of stations with positive and negative trends in annual precipitation indices. 
Table 2. Percentage (\%) of stations with positive or negative trends for extreme precipitation indices over the North Caucasus and the Crimean Peninsula 1961-2018

\begin{tabular}{lccccc}
\hline \hline Index & Sig (+) & Non-sig (+) & Sig $(-)$ & Non-sig $(-)$ & No trend \\
\hline \hline CDD & 8.89 & 37.78 & 2.22 & 11.11 & 40 \\
CWD & 13.33 & - & - & - & 86.67 \\
PRCPTOT & 22.22 & 57.78 & - & 20 & - \\
R10mm & 20 & 22.22 & 4.44 & 8.9 & 44.44 \\
R20mm & 11.11 & 4.44 & 11.11 & 4.44 & 68.9 \\
RX1day & 6.67 & 44.44 & 11.11 & 37.78 & - \\
RX5day & 8.89 & 55.55 & 6.67 & 28.89 & - \\
SDII & 22.22 & 28.9 & 15.55 & 15.55 & 17.78 \\
R95p & 13.3 & 51.2 & 13.3 & 22.2 & - \\
R99p & 8.9 & 4.4 & - & 4.4 & 82.3 \\
\hline
\end{tabular}

The consecutive dry days (CDD) showed a positive (dry) trend at $47 \%$ of all stations, $9 \%$ of them exhibited a statistically significant increase. Significant upward trends were found on the Crimean Peninsula reaching 2-4 days per decade. Results showed that the negative slopes of CDD were concentrated in the Caspian lowland (Fig. 2). Most stations (about 87\%) did not show any trends in wet periods (the CWD index). The stations, where CWD exhibited significant positive trends, were mainly those on the Crimean Peninsula ( +0.3 to 0.6 days/decade). For annual precipitation (PRCPTOT), statistically significant increase was typically observed for the Caspian Sea coast (23 mm/decade in Astrakhan, north coast of the Caspian Sea) and in the Stavropol Upland (9 to $17 \mathrm{~mm} /$ decade). More than $42 \%$ of the stations showed an increase in R $10 \mathrm{~mm}$, but only $20 \%$ of those had a statistically significant change ( 0.3 to 0.5 days/decade on the Caspian Sea coast and 0.9 to 1.1 in the mountains). Significant decrease was observed on the Crimean Peninsula (about -1 day/decade). About $70 \%$ of the stations did not show any change in R20mm. Stations that showed statistically significant increase were concentrated in the Stavropol Upland, where the change reached 0.5 days/decade. As for RX1day, half of the stations had a positive trend, and the rest had a negative trend, which were statistically significant for only $7 \%$ and $11 \%$ of the stations, respectively. Statistically significant decrease was mainly observed on the Crimean Peninsula ( $-5.5 \mathrm{~mm} /$ decade on the west coast of peninsula). As for RX5day, about $65 \%$ of the meteorological stations showed positive trends but only $9 \%$ showed significance, mainly those in the Stavropol Upland ( $4.5 \mathrm{~mm} /$ decade). The Stavropol Upland is the climatic border between the eastern and western part of Ciscaucasia. 
The percentages of stations with positive and negative trends for SDII are $51 \%$ (22\% statistically significant) and 31\% (15\% statistically significant), respectively. Increasing trends for intensity index were observed in the Stavropol Upland and on the coast of the Caspian Sea $(0.1 \mathrm{~mm} /$ day per decade on average), while significant decrease was mainly found on the Crimean Peninsula (ranging from -0.1 to -0.4 $\mathrm{mm} /$ day per decade). For very wet days (R95p), $65 \%$ of the stations showed an upward trend, while $13 \%$ of all stations observed statistically significant changes. Most of the stations situated on the Crimean Peninsula had downward trends for R95p (ranging from -12 to $-22 \mathrm{~mm} /$ decade). In the studied area, about $82 \%$ of meteorological stations did not show any trends in R99p.
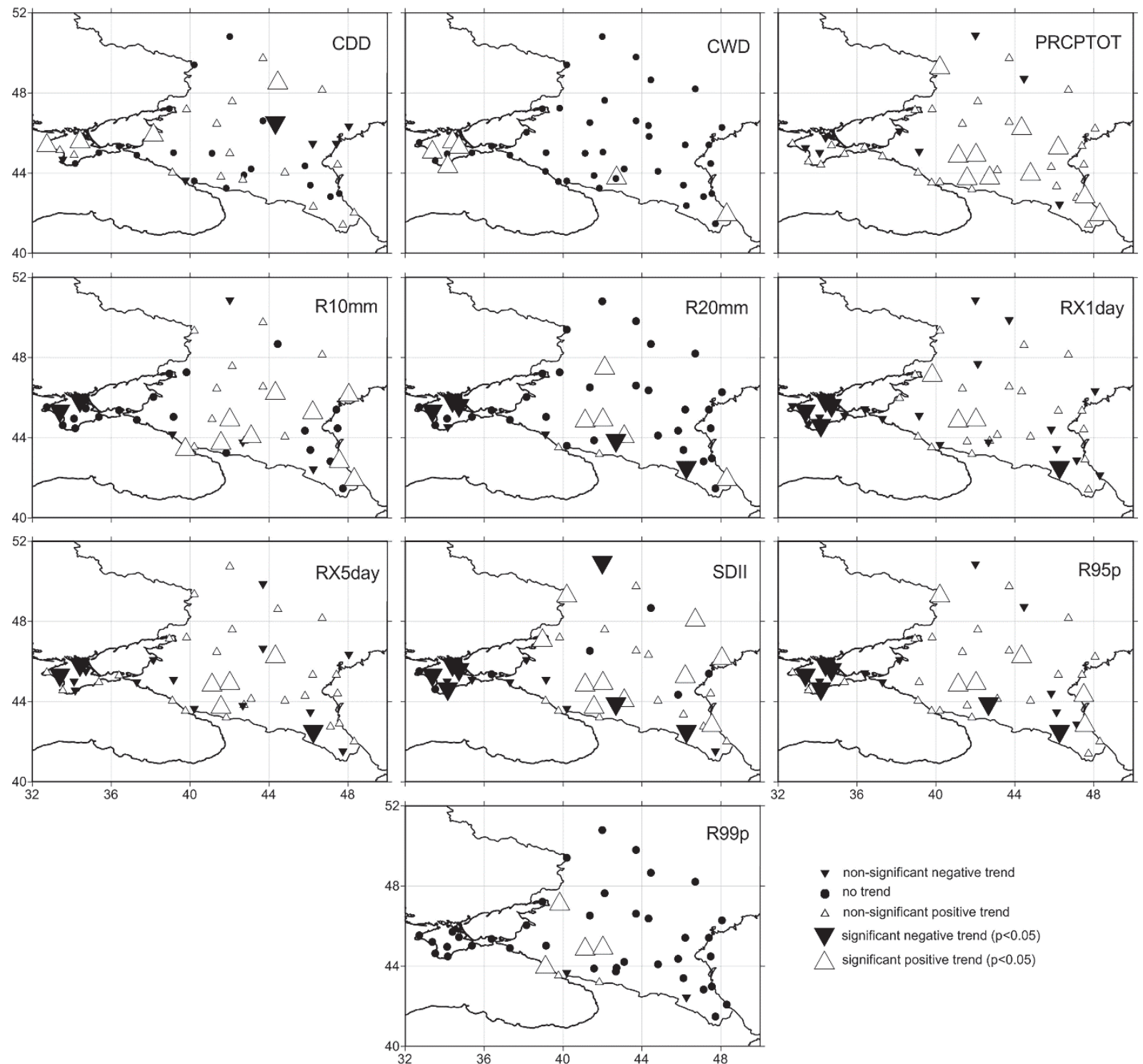

- non-significant negative tren

- no trend

$\Delta$ non-significant positive trend

significant negative trend $(p<0.05)$

$\triangle$ significant positive trend $(p<0.05)$

Fig. 2. Spatial distribution of trends over the North Caucasus and the Crimean Peninsula in 1961-2018. 
Fig. 3 shows the regional average series of extreme precipitation indices. In 1961-2018, all extreme precipitation indices were rising in the studied region, although insignificantly. The regional trend for dry periods (CDD) over 19612018 was 4.5 days/decade. PRCPTOT for the studied area was rising at a rate of $5.4 \mathrm{~mm} /$ decade. Simple daily intensity index (SDII) showed virtually no change in the regional average $(0.1 \mathrm{~mm} /$ day per decade). Fixed-threshold indices (R10mm, R20mm and CWD) changed only slightly ( 0.1 to 0.7 days/decade). Percentile-based indices (R95p and R99p) had upward trends (not significant) and reached 16 and $23 \mathrm{~mm} /$ decade respectively. Maximum 1-day and 5-day precipitation amount also exhibited an upward trend at 3 and $6 \mathrm{~mm} / \mathrm{decade}$, respectively.
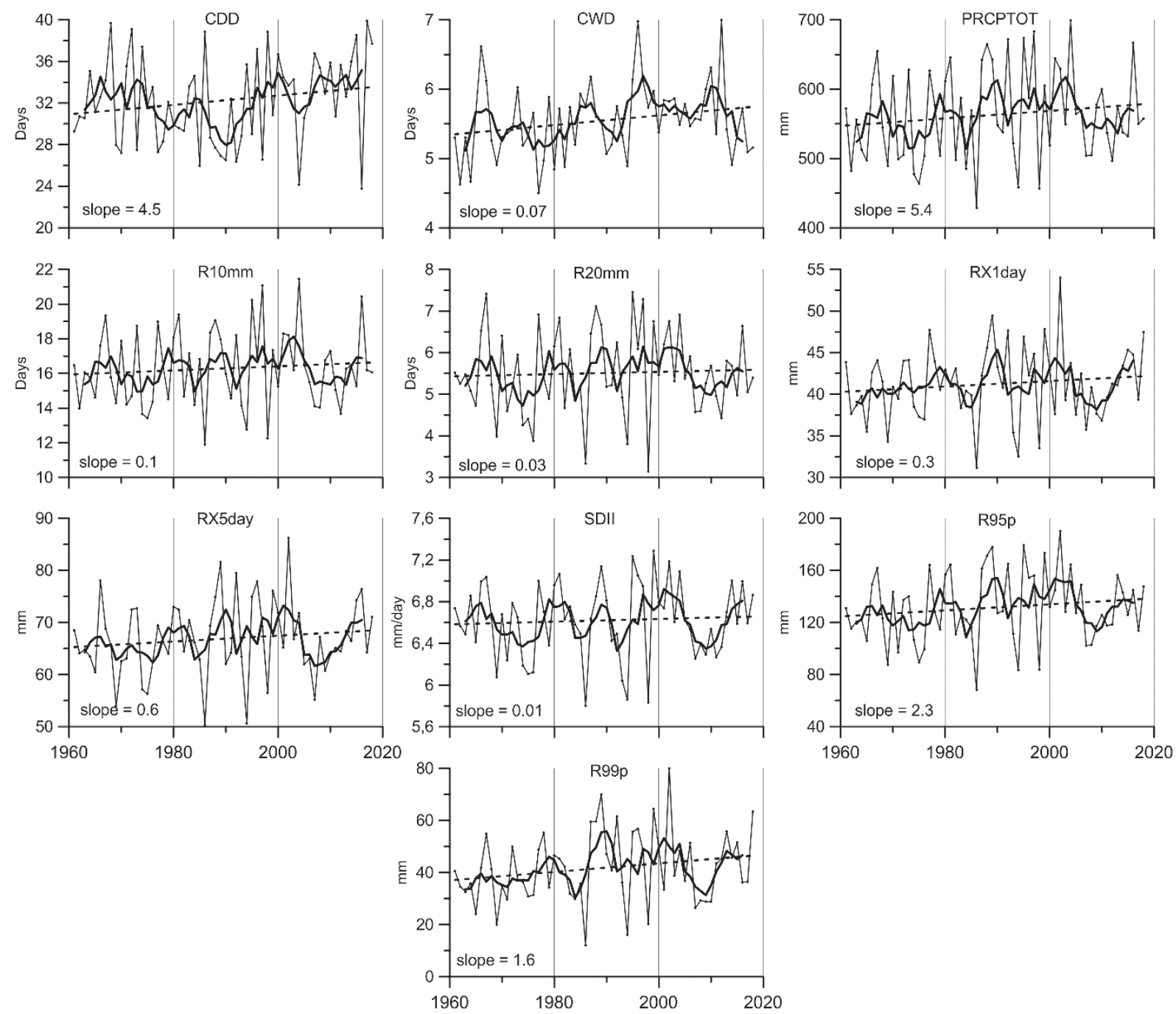

Fig. 3. The regional average series of extreme precipitation indices over 1961-2018. Thin black lines represent average values of indices, bold black lines represent the 5-year moving average, and dotted black lines show trends. The slopes of trends are represented in units per decade. 


\subsection{Changes in the average annual values of extreme precipitation indices}

Fig. 4 shows changes in the average annual values of extreme precipitation indices for 1961-1990 and 1991-2018. In order to examine changes in extreme precipitation indices (and to confirm the observed trends), the probability density functions (PDFs) for each index were calculated for two subperiods: 1961-1990 and 1991-2018.
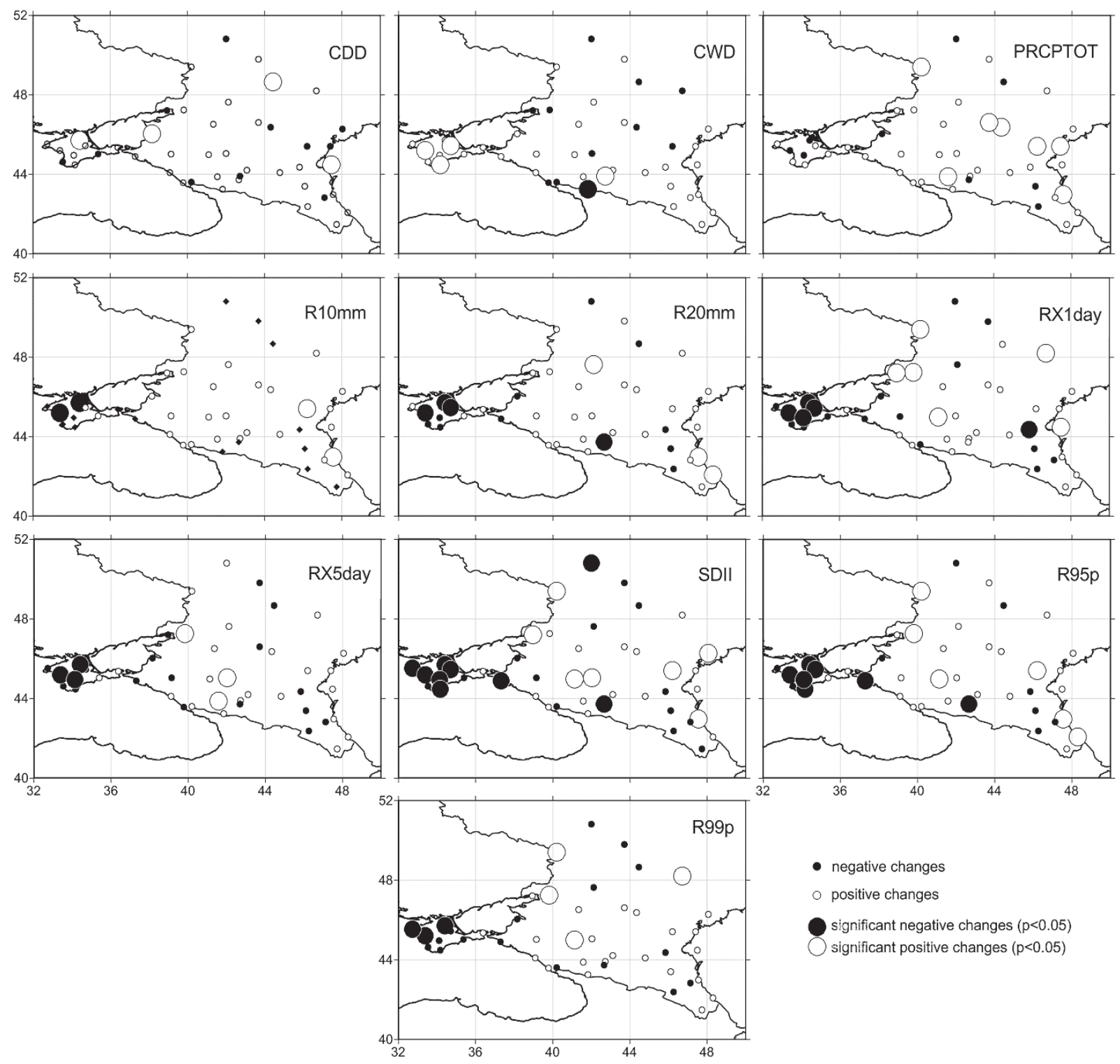

- negative changes

- positive changes

significant negative changes $(p<0.05)$

significant positive changes $(p<0.05)$

Fig. 4. Changes in average annual values of extreme precipitation indices over the North Caucasus and the Crimean Peninsula in 1991-2018 relative to 1961-1990. Negative changes mean decreasing index value in period 1991-2018 compared with period 19611990. Positive changes - vice versa. Significance of changes was determined by the Kolmogorov-Smirnov test on 95\% confidence level. 
The majority of stations did not show any statistically significant shifts (by the Kolmogorov-Smirnov test) in the index distribution between the two subperiods. The duration of dry and wet periods (CDD and CWD) as well as PRCPTOT showed positive changes in the latter period for the studied region (73-80\%). PRCPTOT index exhibited statistically significant increase for the Caspian Sea coast in the latter period $(\mathrm{p}<0.05)$.

Fixed threshold-based indices (R10mm and R20mm) and all intensity indices (RX1day, RX5day, SDII, R95p, and R99p) shifted their distributions towards smaller values for the Crimean Peninsula in the latter period compared to the reference period (statistically significant at $\mathrm{p}<0.05$ ). Number of days with precipitation above 10 and $20 \mathrm{~mm}$ were observed in 1991-2018 for Ciscaucasia with single significant values for the Caspian Sea coast.

\subsection{Correlation between extreme precipitation indices and altitude}

As it was mentioned above, the region has complex orography. Table 3 shows the Pearson correlation coefficients ( $\mathrm{r}$ ) for extreme precipitation indices and altitude. Except for CDD, extreme precipitation indices have positive correlations with altitude, and they all are statistically significant at $95 \%$ confidence level.

Table 3. Correlation coefficients between extreme precipitation indices and altitude in $1961-2018$

\begin{tabular}{ccccccccccc}
\hline \hline & CDD & CWD & PRCPTOT & $\begin{array}{l}\text { R10 } \\
\text { mm }\end{array}$ & $\begin{array}{c}\text { R20 } \\
\text { mm }\end{array}$ & RX1day & RX5day & SDII & R95p & R99p \\
\hline \hline Altitude & -0.41 & 0.51 & 0.43 & 0.43 & 0.35 & 0.32 & 0.39 & 0.31 & 0.43 & 0.44 \\
\hline
\end{tabular}

The North Caucasus can be divided into several zones by the nature of its landscape: plains (0-500 m a.s.1.), foothills (500-1,000 m a.s.1.), mountains (>1,000 $\mathrm{m}$ a.s.1.), and high-mountain (>2,000 $\mathrm{m}$ a.s.1.) (Tashilova et al., 2019). In addition, there are areas below sea level (the Caspian Lowland) were allocated. All Crimean stations are located in the plains (below $500 \mathrm{~m}$ ). Table 4 shows the average values of extreme precipitation indices by the altitudinal ranges.

As it is shown in Table 4, all indices (except CDD) display increasedecrease-increase tendency as the altitude increases. CDD demonstrates an opposite distribution. Decrease in indices (except CDD) is typical for the mountain stations $(1000-2000 \mathrm{~m})$. This range is represented by one station (Akhty), located in the southeast of the studied region. Despite its altitude, the climate of this region is temperate continental with an annual precipitation of about $400 \mathrm{~mm}$. The heterogeneity in the altitudinal changes of extreme 
precipitation index is made by the region of the Black Sea coast of the Caucasus, which is characterized by high average annual precipitation (about $1500 \mathrm{~mm}$ ).

Table 4. Changes of extreme precipitation indices in altitudinal ranges

\begin{tabular}{|c|c|c|c|c|c|c|c|c|c|c|}
\hline $\begin{array}{l}\text { Altitudinal } \\
\text { ranges (m) }\end{array}$ & $\begin{array}{c}\text { CDD } \\
\text { (days) }\end{array}$ & $\begin{array}{l}\text { CWD } \\
\text { (days) }\end{array}$ & $\begin{array}{l}\text { PRCPTOT } \\
\quad(\mathbf{m m})\end{array}$ & $\begin{array}{c}\text { R10 } \\
\text { mm } \\
\text { (days) }\end{array}$ & $\begin{array}{c}\mathrm{R} 20 \\
\mathrm{~mm} \\
\text { (days) }\end{array}$ & $\begin{array}{c}\text { RX1 day } \\
\text { (mm) }\end{array}$ & $\begin{array}{c}\text { RX5day } \\
\text { (mm) }\end{array}$ & $\underset{\text { (mm/day) }}{\text { SDII }}$ & $\begin{array}{l}\text { R95p } \\
\text { (mm) }\end{array}$ & $\begin{array}{l}\text { R99p } \\
(\mathrm{mm})\end{array}$ \\
\hline & & 3.9 & 242.9 & 5.8 & 1.5 & & & & 64.6 & 23.5 \\
\hline $0-500$ & 32.1 & 5.4 & 515.2 & 14.5 & 4.5 & 40.0 & 62.9 & 6.4 & 121.1 & 38.8 \\
\hline $500-1000$ & 24.7 & 7.5 & 1102.7 & 35.4 & 15.3 & 55.7 & 107.4 & 9.3 & 237.2 & 65.9 \\
\hline $1000-2000$ & 35.3 & 4.4 & 376.3 & 10.7 & 2.4 & 31.7 & 46.5 & 5.9 & 79.9 & 24.1 \\
\hline$>2000$ & 23.4 & 8.0 & 1131.0 & 35.2 & 14.3 & 60.2 & 114.2 & 8.9 & 266.7 & 86.2 \\
\hline
\end{tabular}

\section{Discussion and conclusions}

This paper dwells upon the spatial and temporal distribution of climate extremes indices for the North Caucasus and the Crimean Peninsula. The analysis is based on the climate data for 1961-2018 from 45 meteorological stations. Climate extremes indices recommended by the World Meteorological Organization (CCL/CLIVAR/JCOMM) and the Expert Team on Climate Change Detection and Indices (ETCCDI) were used. The use of these indices enables comparison of analyses carried out in any regions and combining them in a global picture (Zhang et al., 2011).

Analysis shows that all indices (except CDD) peak for the Black Sea coast of Caucasus, while the Caspian Sea coast and the Caspian Lowland have the lowest values, which is due to the features of atmospheric circulation over this region and to the complex orography. The greatest amount of precipitation is associated with westerly winds that carry moisture from the Atlantic. Their humidity is then subject to the interference from the slopes of the mountains and hills facing west, and in the east, the climate becomes drier and more continental (Vyshkvarkova et al., 2018).

Extreme precipitation trends are spatially incoherent and mostly statistically insignificant in the studied territory. Statistically significant downward trends in the fixed threshold-based indices and all intensity indices were detected for the Crimean Peninsula. At the same time, the Stavropol Upland had statistically significant upward trends in these indices as well as in PRCPTOT. Both dry and wet periods have been growing longer simultaneously on the Crimean Peninsula. 
A similar trend was observed for some regions of the central and southern part of European Russia in 1950-2009 (Zolina et al., 2013). Statistically significant downward changes in the average annual extreme precipitation indices (except the duration of dry and wet periods and the precipitation amount) were detected for the Crimean Peninsula. Precipitation indices (except consecutive dry days) and altitude were found to correlate positively and significantly.

Neither Russia nor the Caucasus show clear signs in the changes of extreme precipitation regime. The results obtained in the article are consistent with the regional changes in extreme precipitation observed in the southern part of European Russia. Aleshina et al. (2018) found significant trends in precipitation intensity and total monthly precipitation for no more than two months a year on the Black Sea coast over 1984-2014. Extreme precipitation growth (R95tot index) of up to 3\% per decade was observed for the southern part of European Russia in 1950-2000 (Zolina et al., 2009). Bulygina et al. (2007) did not identify significant changes in days with extremely large daily precipitation when comparing 19512006 records to 1977-2006 records for Southern Russia.

According to the Second Roshydromet Assessment Report on Climate Change and its Consequences in the Russian Federation (2014) in winter, throughout the 21 st century for all scenarios, there is a steady positive trend in precipitation all over Russia. Summer precipitation in the southern regions is projected to drop by up to $25 \%$ compared to the late 20th century. Maximum fiveday precipitation in a year will increase by the mid-21st century; by the end of the current century, they will rise by up to $10 \%$ against the baseline. In the southern regions (including the Caucasus Mountains), the significant relative increase in the precipitation intensity maximum is expected by the middle of the 21 st century according to the CMIP5 ensemble projections (Khlebnikova et al., 2019). At the same time, the frequency of extreme precipitation will decrease in the southern parts of Russia by the end of the 21st century according to results obtained by Aleshina et al. (2019). Apparently, there is no clear signal of changes in extreme precipitation in the future

Redistribution of precipitation throughout the year, observed changes in precipitation regime, and possible changes in the intensity and frequency of extreme precipitation events in the future are becoming one of the main threats facing the region. The studied region has had to address water shortages in recent years (poor filling of reservoirs in the Crimea and Krasnodar Krai). This provides a more detailed picture of the spatially coherent trends in precipitation extremes over the territory of the North Caucasus and the Crimean Peninsula. It also calls for further research of different periods of the year (not only seasons), for example, for the vegetation periods of different crops, because Ciscaucasia is an agricultural region. Due to its complex orography, part of the studied area is floodprone, while droughts and related problems (crop loss, reservoir underflow, etc.) are possible in other parts. 
Acknowledgment: The author would like to thank Evgeniy Rybalko for his technical assistance and is grateful to the editor and anonymous reviewer, for their helpful comments on the manuscript.

Funding: The study was supported by state assignment of Institute of Natural and Technical Systems (Project Reg. No. AAAA-A19-119031490078-9). Analysis of precipitation in Sevastopol region was funded by RFBR and Sevastopol, project number 20-45-920008.

\section{References}

Aleshina, M.A., Toropov, P.A., and Semenov, V.A., 2018: Temperature and humidity regime changes on the Black Sea coast in 1982-2014. Rus. Meteor. Hydrol. 4, 41-53. https://doi.org/10.3103/S1068373918040040

Aleshina, M.A., Cherenkova, E.A., Semenov, V.A., Bokuchava, D.D., Matveeva, T.A., and Turkov, D.V., 2019: Observed and expected changes in extreme precipitation frequency in Russia in the 20th21st centuries. Proc. SPIE 11208. https://doi.org/10.1117/12.2540921

Alexander, L., Zhang, X., Peterson, T., Caesar, J., Gleason, B., Klein Tank, A., Haylock, M., Collins, D., Trewin, B., Rahimzadeh, F., Tagipour, A., Ambenje, P., Rupa Kumar, K., Revadekar, J., Griffiths, G., Vincent, L., Stephenson, D., Burn, J., Aguilar, E., Brunet, M., Taylor, M., New, M., Zhai, P., Rusticucci, M., and Vazquez Aguirre, J., 2006: Global observed changes in daily climate extremes of temperature and precipitation. J. Geoph. Res. Atmos. 111, D05109. https://doi.org/10.1029/2005JD006290

Ashabokov, B.A., Bischokov, R.M., and Derkach, D.V., 2008: Study of changes in the regime of atmospheric precipitation in the Central Northern Caucasus. Russ. Meteor. Hydrol. 33, 125-129. https://doi.org/10.3103/S1068373908020106

Ashabokov, B.A., Tashilova, A.A., Kesheva, L.A., and Taubekova, Z.A., 2017: Trends in precipitation parameters in the climate zones of Southern Russia (1961-2011). Rus. Meteor. Hydrol. 42, 150158. https://doi.org/10.3103/S1068373917030025

Bartolomeu, S., Carvalho, M.J., Marta-Almeida, M., Melo-Gonçalves, P., and Rocha, A., 2016: Recent trends of extreme precipitation indices in the Iberian Peninsula using observations and WRF model results. Phys.chemistry Earth. Parts A/B/C 94, 10-21.

https://doi.org/10.1016/j.pce.2016.06.005

Brown, P.J., Bradley, R.S., and Keimig, F.T., 2010: Changes in extreme climate indices for the Northeastern United States, 1870-2005. J. Climate 23, 6555-6572.

https://doi.org/10.1175/2010JCLI3363.1

Bulygina, O.N., Razuvaev, V.N., Korshunova, N.N., and Groisman, P.Ya., 2007: Climate variations and changes in extreme climate events in Russia. Environ. Res. Lett. 2, 045020. https://doi.org/10.1088/1748-9326/2/4/045020

Changnon, S.A., Pielke Jr., R.A., Changnon, D., Sylves, R.T., and Pulwarty, R., 2000: Human factors explain the increased losses from weather and climate extremes. Bull. Am. Meteorol. Soc. 81, 437-442. https://doi.org/10.1175/1520-0477(2000)081<0437:HFETIL >2.3.CO;2

Chernokulsky, A.V., Kozlov, F.A., Zolina, O.G., Bulygina, O.N., and Semenov, V.A., 2018: Climatology of precipitation of different genesis in Northern Eurasia. Rus. Meteor. Hydrol. 43, 425-435. https://doi.org/10.3103/S1068373918070014

Degefie, D.T., Fleischer, E., Klemm, O., Soromotin, A.V., Soromotina, O.V., Tolstikov, A.V., and Abramov, N.V., 2014: Climate extremes in South Western Siberia: past and future. Stoch. Environ. Res. Risk Assess. 28, 2161-2173. https://doi.org/10.1007/s00477-014-0872-9

Dodge, Y., 2008. The Concise Encyclopedia of Statistics. Springer Science + Business Media, LLC.

Donat, M.G., Alexander, L.V., Yang, H., Durre, I., Vose, R., Dunn, R.J.H., Willett, K.M., Aguilar, E., Brunet, M., Caesar, J., Hewitson, B., Jack, C., Klein Tank, A.M.G., Kruger, A.C., Marengo, J., Peterson, T.C., Renom, M., Oria Rojas, C., Rusticucci, M., Salinger, J., Elrayah, A.S., Sekele, S.S., Srivastava, A.K., Trewin, B., Villarroel, C., Vincent, L.A., Zhai, P., Zhang, X., and Kitching, S., 2013: Updated analyses of temperature and precipitation extreme indices since the beginning of the twentieth century: the HadEX2 dataset. J. Geophys. Res. Atmos. 118, 1-16. https://doi.org/10.1002/jgrd.50150 
Frich, P., Alexander, L.V., Della-Marta, P.M., Gleason, B., Haylock, M., Tank, A.K., and Peterson, T., 2002: Observed coherent changes in climatic extremes during the second half of the twentieth century. Clim. Res. 19, 193-212. https://doi.org/10.3354/cr019193

Hamed, K. and Rao, A., 1998: A modified Mann Kendall trend test for autocorrelated data. J. Hydrol. 204, 182-196. https://doi.org/10.1016/S0022-1694(97)00125-X

Hartmann, D.L., Klein Tank, A.M.G., Rusticucci, M., Alexander, L.V., Brönnimann, S., Charabi, Y., Dentener, F.J., Dlugokencky, E.J., Easterling, D.R., Kaplan, A., Soden, B.J., Thorne, P.W., Wild, M., and Zhai, P.M., 2013. Observations: atmosphere and surface. In: Stocker, T.F., Qin, D., Plattner, G.-K., Tignor, M., Allen, S.K., Boschung, J., Nauels, A., Xia, Y., Bex, V., and Midgley, P.M. (Eds.), Climate Change 2013: The Physical Science Basis. Contribution of Working Group I to the Fifth Assessment Report of the Intergovernmental Panel on Climate Change. Cambridge University Press, Cambridge, United Kingdom and New York, NY, USA. https://doi.org/10.1017/CBO9781107415324.008

IPCC, 2014: Climate change 2014: synthesis report. Contribution of Working Groups I, II and III to the Fifth Assessment Report of the Intergovernmental Panel on Climate Change (Eds. Core Writing Team, Pachauri, R.K. and Meyer, L.A.) IPCC, Geneva.

Khan, M.J.U., Islam, A.K.M.S., Das, M.K., Mohammed, K., Bala, S.K., and Islam, G.M.T., 2019: Observed trends in climate extremes over Bangladesh from 1981 to 2010. Clim. Res. 77, 45-61. https://doi.org/10.3354/cr01539

Khlebnikova, E.I., Rudakova, Yu.L., and Shkolnik, I.M., 2019: Changes in precipitation regime over the territory of Russia: data of regional climate modeling and observations. Russ. Meteor. Hydrol. 44, 431-439. https://doi.org/10.3103/S106837391907001X

Klein Tank, A.M.G., and Konnen, G.P., 2003. Trends in indices of daily temperature and precipitation extremes in Europe, 1946-1999. J. Clim. 16, 3665-3680. https://doi.org/10.1175/1520-0442(2003)016<3665:TIIODT>2.0.CO;2

Kotlyakov, V.M., Desinov, L.V., Dolgov, S.V., Koronkevich, N.I., Likhacheva, E.A., Makkaveev, A.N., Medvedev, A.A., and Rudakov, V.A., 2013: Flooding of July 6-7, 2012, in the town of Krymsk. Regional Research of Russia 3, 32-39. https://doi.org/10.1134/S2079970513010061

Limsakul, A. and Singhruck, P., 2016. Long-term trends and variability of total and extreme precipitation in Thailand. Atmos. Res. 169, 301-317. https://doi.org/10.1016/j.atmosres.2015.10.015

Liu, W., Zhang, M., Wang, S., Wang, B., Li, F., and Che, Y., 2013: Changes in precipitation extremes over Shaanxi Province, northwestern China, during 1960-2011. Quat. Int. 313-314, 118-129. https://doi.org/10.1016/j.quaint.2013.06.033

Lupikasza, E., 2010: Spatial and temporal variability of extreme precipitation in Poland in the period 1951-2006. Int. J. Climatol. 30, 991-1007. https://doi.org/10.1002/joc.1950

Mann, H.B., 1945: Nonparametric tests against trend. Econometrica 13, 245-259. https://doi.org/10.2307/1907187

Mathbout, S., Lopez-Bustins, J.A., Roye, D., Martin-Vide, J., Bech, J., and Rodrigo, F.S., 2018: Observed changes in daily precipitation extremes at annual timescale over the Eastern Mediterranean during 1961-2012. Pure Appl. Geophys. 175, 3875-3890. https://doi.org/10.1007/s00024-017-1695-7

Martin-Vide, J., 2004: Spatial distribution of a daily precipitation concentration index in Peninsular Spain. Int. J. Climatol. 24, 959-971. https://doi.org/10.1002/joc.1030

Meredith, E.P., Semenov, V.A., Maraun, D., Park, W., and Chernokulsky, A.V., 2015. Crucial role of Black Sea warming in amplifying the 2012 Krymsk precipitation extreme. Na. Geosci. 8, 615619. https://doi.org/10.1038/ngeo2483

Nie, H., Qin, T., Yang, H., Chen, J., He, S., Lv, Z., and Shen, Z., 2019: Trend analysis of temperature and precipitation extremes during winter wheat growth period in the major winter wheat planting area of China. Atmosphere 10, 240. https://doi.org/10.3390/atmos10050240

Popov, T., Gnjato, S., and Trbić, G., 2018: Analysis of extreme precipitation over the Peripannonian region of Bosnia Hercegovina. Időjárás 122 , 433-452.

https://doi.org/10.28974/idojaras.2018.4.5

Ray, D., Gerber, J., MacDonald, G., and West, P., 2015: Climate variation explains a third of global crop yield variability. Nat Commun. 6, 5989. https://doi.org/10.1038/ncomms6989 
Sayemuzzaman, M. and Jha, M.K., 2014: Seasonal and annual precipitation time series trend analysis in North Carolina, United States. Atmos. Res. 137, 183-194.

https://doi.org/10.1016/j.atmosres.2013.10.012

Second Roshydromet Assessment Report on Climate Change and its Consequences in the Russian Federation. General summary, 2014: Moscow, Roshydromet.

Sen, P.K., 1968: Estimates of the regression coefficient based on Kendall's tau. J. Am. Stat. Assoc. 63, 1379-1389. https://doi.org/10.1080/01621459.1968.10480934

Tashilova, A.A., Ashabokov, B.A., Kesheva, L.A., and Teunova, N.V., 2019: Analysis of climate change in the Caucasus region: end of the 20th-beginning of the 21 st century. Climate 7, 11. https://doi.org/10.3390/cli7010011

Titkova, T.B., Cherenkova, E.A., and Semenov, V.A., 2018: Regional features of changes in winter extreme temperatures and precipitation in Russia in 1970-2015. Ice and Snow 58, 486-497. (In Russian). https://doi.org/10.15356/2076-6734-2018-4-486-497

Tong, S., Li, X., Zhang, J., Bao, Y., Bao, Y., Na, L., and Si, A., 2019: Spatial and temporal variability in extreme temperature and precipitation events in Inner Mongolia (China) during 1960-2017. Sci. Tot. Environ. 649, 75-89. https://doi.org/10.1016/j.scitotenv.2018.08.262

Vyshkvarkova, E., Voskresenskaya, E., and Martin-Vide, J., 2018: Spatial distribution of the daily precipitation concentration index in Southern Russia. Atmos. Res. 203, 36-43. https://doi.org/10.1016/j.atmosres.2017.12.003

Wang, B.L., Zhang, M.J., Wei, J.L., Wang, S.J., Li, S.S., Ma, Q., Li, X.F., and Pan, S.K., 2013: Change in extreme events of temperature and precipitation over Xinjiang, northwest China, during 19602009. Quat. Int. 298, 141-151. https://doi.org/10.1016/j.quaint.2012.09.010

Wang, H., Chen, $Y$., and Chen, Z., 2012: Spatial distribution and temporal trends of mean precipitation and extremes in the arid region, northwest of China, during 1960-2010. Hydrol. Process. 27, 1807-1818. https://doi.org/10.1002/hyp.9339

Yang, H., Xiao, H., Guo, C., and Sun, Y., 2019: Spatial-temporal analysis of precipitation variability in Qinghai Province, China. Atmos. Res. 228, 242-260. https://doi.org/10.1016/j.atmosres.2019.06.005

Ye H., 2018: Changes in duration of dry and wet spells associated with air temperatures in Russia. Environ. Res. Lett. 13, 034036. https://doi.org/10.1088/1748-9326/aaae0d

Zhang, H., Wang, Y., Won Park, T., and Deng, Y., 2017: Quantifying the relationship between extreme air pollution events and extreme weather events. Atmos. Res. 188, 64-79. https://doi.org/10.1016/j.atmosres.2016.11.010

Zhang, X. and Yang, F., 2004: RClimDex (1.0) User Guide. Climate Research Branch Environment. Canada, Downsview (Ontario, Canada).

Zhang, X., Alexander, L., Hegerl, G.C., Jones, P., Klein Tank, A., Peterson, T.C., Trewin, B., and Zwiers, $F . W$., 2011: Indices for monitoring changes in extremes based on daily temperature and precipitation data. WIREs Clim. Change 2, 851-870. https://doi.org/10.1002/wcc.147

Zolina, O., Simmer, C., Belyaev, K., Kapala, A., and Gulev, S., 2009: Improving estimates of heavy and extreme precipitation using daily records from European rain gauges. J. Hydrometeorol. 10, 701716. https://doi.org/10.1175/2008JHM1055.1

Zolina, O., Simmer, C., Belyaev, K., Gulev, S., and Koltermann, P., 2013: Changes in the duration of European wet and dry spells during the last 60 years. J. Clim. 26, 2022-2047. https://doi.org/10.1175/JCLI-D-11-00498.1

Zolotokrylin, A. and Cherenkova, E., 2017. Seasonal changes in precipitation extremes in Russia for the last several decades and their impact on vital activities of the human population. Geograp. Environ. Sustainab. 10, 69-82. https://doi.org/10.24057/2071-9388-2017-10-4-69-82 